\title{
THE PARTICIPATION OF POLISH FEMALE SOLDIERS IN WORLD WAR I
}

\author{
Iwona SZKUDLAREK \\ War Studies University, iwonaszkudlarek@onet.eu; ORCID: 0000-0001-7125-7004
}

\begin{abstract}
Purpose: The aim of this paper is to outline a history of the participation of Polish female soldiers in the World War I. Its outlines their commitment, struggle, and efforts made to contribute to Poland's military effort during the war. The article describes the legal situation of the military participation of women in Poland, and also deals with their role and place in society. Design/methodology/approach: The aim of the article was to organize, systematize and describe the knowledge about the role and participation of female soldiers of the Polish armed forces during the World War I. The above theoretical goal has been achieved by applying the methods of analysis, synthesis, deduction, induction and inference.

Findings: In the course of the work were found results, which testify to historically underestimated contribution of women in war efforts. These, both in reinforcement and in other spheres of hostilities significantly contributed to the end of the war and its final result.

Social implications: Publication of the article may contribute to increasing social awareness of the underestimated participation and involvement of female soldiers in military action during the war and of the social and cultural roles they fulfill.

Originality/value: The article organizes and systematizes the knowledge about the military service of women in the described period. It is addressed both to people associated with all kinds of uniformed services, management and command, as well as people from the civilian environment.
\end{abstract}

Keywords: Polish Soldiers, Female Soldiers, World War I, Polish Armed Forces, Participation of Women in Armed Forces.

\section{Introduction}

As de Beauvoir writes in her book The Second Sex: (...) man rises above the animal not by giving life, but by risking it; therefore humanity places higher not the sex that gives birth, but the sex that kills (Beauvoir, 2003, p. 84). According to the French philosopher, the marginalisation of women in Western culture was directly connected to their exclusion from warfare. They were joined by full-fledged entities - which women, children and old people were not - ready to sacrifice their own lives in the name of communal, abstract, supra-individual 
values, important from the perspective of the community's survival, which they did at the expense of sacrificing personal happiness. Thanks to this they were distinguished, admired and celebrated in culture. A warrior, a knight, a soldier, just like a thinker, a researcher, or a scientist (struggling with nature and its mysteries) are ready to give up their personal, social, or family life in the name of achieving higher goals, usually with the full understanding of their surroundings (Derra, 2013).

For years or even centuries, the military has been associated with a masculinised, malecommanded military. Although women have participated in wars throughout history, this fact was caused by crises in the form of a shortage of men or a state of emergency. These were situations of an impermanent and irregular nature, resulting from the need of the moment, and therefore also unregulated by customs and, moreover, by law. This phenomenon was mainly due to the lower social position of women than men.

However, with the advent of more widespread access to education for women, followed by opportunities for gainful employment, the status of women has slowly changed. This included both social and occupational status, and then economic and political status.

The period of World War I was a watershed when the first attempts were made to organise women's military service. In 1918, Poland regained its independence and women were given the right to vote. Afterwards, women were involved to a much greater extent in the fighting during World War II in order to start legally regulated women's military service in specific corps from 1989.

As mentioned earlier, World War I saw a major breakthrough for women who wanted to enter military service. This is when the first attempts are made to create regular female military formations. The failures of the uprisings further aroused the fighting spirit of Poles and Polish women, resulting in the regaining of independence in 1918.

Receiving basic military training before World War I was accomplished in the form of women's participation in shooting squads, scouting or the Union of Polish Youth. Women fulfilled their duty to their homeland during World War I and the war with the Bolsheviks by serving in the Polish Legions, the Polish Military Organization (PMO), and the Women's Voluntary Legion (WVL) (Formalno-prawne, 2002).

\section{Participation of women in legionary formations}

The beginnings of women's activity in the Polish Legions date back to the years 1910-1912, when in Galicia women were allowed to participate in paramilitary work. Initially, these were women's sections operating alongside the men's Riflemen's Associations and then, from 1912, independent female paramilitary units. This happened even before the outbreak of war, thanks to Piłsudski's clear position: I believe that women are suitable for any auxiliary service in the 
army, at the front and at the back of the army. I have thought over these matters and believe that work in strictly military formations is not suitable for women, but elsewhere (...) for any work they can be used to replace men and thus increase the ranks of the army (Piłsudska, 1955, p. 182).

According to Piłsudski's predictions, the war with Russia was to be guerrilla-oriented, and the members of the riflemen's units were to form the basis of the courier-intelligence and sabotage operations of the Kingdom of Poland. As a result, the training program was adjusted to these assumptions and covered the scope of organisation and deployment of the Russian army, terrain studies, diversionary techniques, communications, and field service. These predictions came true after the outbreak of war on 6 August 1914.

In the second half of August 1914, the riflemen's units were transformed into the Polish Legions. From 8 September 1914 the Legions were transferred to the Austrian ordnance's staff, as a result of which they were supplied from Austro-Hungarian uniform warehouses. These changes resulted in Piłsudski issuing an order on 10 September 1914, directing that all women who were with the army be sent back to Kraków. This order gave rise to the removal of women from service in the line units, whose involvement was deemed unnecessary at this stage of the Polish Army's formation. The second reason for this may have been the reluctance shown by legionnaires towards female legionnaires at the front, even those serving as nurses or supply officers. It was probably too much of a challenge for the men, who did not know how they were supposed to relate to the presence of female legionnaires in frontline units. However, there are not enough sources to say conclusively whether this phenomenon was negative.

Some female riflemen, however, found jobs directly related to the military formations. These included Alina Pytlakowska (a nurse in the First Brigade of the Legions) or Barbara Kossuthówna and Ludmiła Modzelewska (who served in a field and military hospital). Selected women also served in the Female Intelligence Unit (formed in August-September 1914), which was part of the Intelligence Unit of the Polish Armed Forces, later renamed the Intelligence Unit of the 1st Infantry Regiment (until 27 August), and from December 1914 already functioning under the name of the Intelligence Unit of the 1st Brigade of the Legions.

The commander of the women's courier and intelligence service of the Intelligence Unit was Rajmund Jaworski, but it was Aleksandra Szczerbińska who managed it on a daily basis. Women who knew Russian were admitted to the Unit, mainly students, and the age range of female intelligence officers was from 20 to 65 .

The activity of the Intelligence Unit itself should be divided into the first period, which lasted from August 1914 until the withdrawal of Piłsudski's army from 16-24 September near Nowy Korczyn and Opatowice. During this period tactical intelligence was conducted in the planned areas of warfare. From December 1914 the second period is distinguished, when the Intelligence Unit was liquidated (April 1915) and women intelligence officers operate in the conditions of the positional warfare performing mainly courier functions (Dufrat, 2001). 
On the basis of an order dated 25 March 1915, it was decided to disband the Intelligence Unit of the First Brigade, which lasted until the end of the year (Dufrat, 2001). It was connected with a crisis in relations between Piłsudski and the Austrian military authorities.

The final number of women serving in the frontline units of the Legions is impossible to determine, since no archives have survived. Undoubtedly, all female legionnaires performed their service with courage and dedication, although only a few were able to demonstrate their skills on the battlefield. The only woman we know was active on the frontlines was Wanda Gertzówna.

Despite the dissolution of the Intelligence Unit, many women did not finally part with military service. As early as 1918-1921 the members of the first Polish women's military formation took part in the Polish-Ukrainian fights in Eastern Galicia. Among them were Zofia Plewińska, Janina Prus-Niewiadomska, Olga Stawecka, Ludwika Daszkiewiczowa and Wanda Gertz, who commanded the Vilnius WVL Battalion during the defence of Vilnius, while Olga Stawecka was commander of the WVL Battalion in Lviv and commanded the WVL Company during the defence of Vilnius.

In summary, 46 women were involved in the service of the Intelligence Unit. Twenty of them were decorated with the First Brigade Badge for Faithful Service by Commander Piłsudski in 1917. Seventeen couriers were nominated for the Cross of Valour. Seven women were awarded the Order of Virtuti Militari. Importantly, despite the Russian search, not a single female courier was killed during her intelligence service.

\section{Polish Military Organisation}

In 1913 the Polish Women's League of Emergency Service began its underground activity in the Kingdom of Poland. Similarly in the Austrian partition the League of Women of Galicia and Silesia was founded in 1914. Both organisations joined forces and led to the creation of female branches of the Polish Military Organisation (PMO) founded by Józef Piłsudski. The tasks of these branches included participating in the work of the technical department or running a passport office. As a result of the decision of the PMO command, after the mobilisation of August 1915, the women's units were disbanded, as a result of which they could not take part in the military activities. However, in October of the same year, the situation changed as a result of the appeal issued by the Supreme Command for women to re-establish cooperation with the underground. Subsequently, subdivisions were organised into sections and platoons, in accordance with the organisation of the army in force at that time. Moreover, in 1916, the historic oath of women soldiers of PMO from the Warsaw district took place (Nałęcz, 1984). Membership in the POW entailed such tasks as intelligence work, gathering weapons, courier and office work, and preparing equipment for combat. At the end of the 
occupation, the organisation had about 800 women in its ranks, working in 18 cells (Nałęcz, 1984).

Thanks to the Bolsheviks' conviction that Polish women were not involved in military cooperation, they were subjected to less frequent inspections. Initially, this allowed them to effectively fulfil the role of liaison officers and work for the intelligence service. Once the method of transmitting information stitched into clothing was exposed, the risk of intelligence service increased significantly. In 1920 alone, 108 "PMO women" were executed in the East, and the number was growing. 87 women were decorated with the Cross of Valour and 21 were awarded the Virtuti Militari Order, 16 of them posthumously (Pepłoński, 2003). Jadwiga Barthel de Weydenthal and Maria Kwiatkowska-Stefanowska, who served as commanders of the women's unit, were particularly distinguished during the intelligence operations of the PMO (Kozłowski, Wrzosek, 1984). Wanda Gertz (known at the front as Kazimierz Żuchowicz), who was engaged in service in the Warsaw Battalion formed in 1915, should also be mentioned as one of the distinguished female soldiers. This battalion fought at the front, where women were forbidden to serve in line service, even though they worked in barracks, performed administrative functions, sewed uniforms, and completed soldiers' equipment (Nowakowska, 2009).

\section{Women's Voluntary Legion}

Despite the end of World War I as a result of the signing of an armistice between Germany and the Allies, security and order in the areas previously affected by the conflict was not so obvious. In Greater Poland the Guard and Security Service and the Civic Guard were organised. Similarly, in the eastern lands the situation was uneasy. In November 1918 Lviv was taken over by the Ukrainians, which resulted in the members of the Polish Women's Citizens' Committee, such as Maria Dulębianka, Michalina Mościcka and Aleksandra Zagórska, taking up the task of defending the city. The City Civic Guard, which was formed at that time, took the initiative of creating its female branches, as a result of which the Women's Civic Militia (MCM) was created. It was divided into three groups:

- battle group - obliged to take part in fighting in case it occurs in the city,

- civic group - not obliged to take part in direct fighting,

- courier group - assigned to liaison service between military commands and the Municipal Citizen Guard.

The MCM, as a non-military formation, could not guarantee women the right to remuneration and supplies. This prompted the organisation's main activists to approach the city with the initiative of transforming the MCM from a militia organisation into a military formation - the Women's Volunteer Legion (WVL). The WVL was formed in 1918 in Lviv as 
a Polish volunteer military organisation. It functioned until 1921, when it was liquidated (Marcinkiewicz-Gołaś, 2006). The WVL should be regarded as the first regular female formation, created in connection with the battles for Lviv and Vilnius Nowakowska. It also made its mark in the Polish-Soviet War, and had its counterpart only in Finland (Dadej, Abryszeński, 2019).

At that time the need for this type of organisation was great, which resulted from the unsettled situation in Lviv, where robberies, thefts, and organised looting were commonplace. As a result of women's conscientious and compulsory service, the Second Voluntary League of Women (SVLW) was founded in May 1919 in the Vilnius area by the command of the Lithuanian-Belarusian Front, and Wanda Gertz was appointed its commander. The rules of service in the VLW consisted primarily of guard, stage and patrol duties, and in justified cases, first-line service. The SVLW was intended to serve as an auxiliary (Skrabacz, 2008), and the rules of Organisation of the SVLW stated that:

- women's divisions are treated as divisions of the Polish army,

- they are not intended to serve at the front,

- in the military service the natural predispositions of women are taken into account,

- preference is given to administrative, guard and communications service,

- With the exception of guard duty, women are forbidden to serve with arms.

Despite the assumption that the VLW was to be an auxiliary formation, in reality women took an active part in the battles for Lviv and Vilnius, as well as Warsaw. In the defence of Lviv 427 women, known by name, took part, of whom 17 fought with arms. The ashes of 66 women are in the Defenders of Lviv Cemetery (Klimecki 2012). A detailed numerical listing of women and men in the defence of Lviv is presented in Table 1. below.

\section{Table 1.}

Participation of women and men in the defence of Lviv

\begin{tabular}{|l|l|l|}
\hline Type of service & Number of women & Service with weapons \\
\hline Armed service & 17 & 3994 \\
\hline Auxiliary service & 410 & 1601 \\
\hline Total female in service & 427 & - \\
\hline Total men in service & - & 5594 \\
\hline Total women and men in service & 6022 & \\
\hline
\end{tabular}

Source: „Obrona Lwowa 1-22 listopada 1918 r. Organizacja listopadowej obrony Lwowa. Ewidencja uczestników walk", Volume III, Warsaw 1994.

As a result of the threat to the capital, in August 1920 a decision was made to form a volunteer line battalion in the strength of two companies, which consisted of about 400 female legionnaires (Skrabacz). In total, 28 women and several thousand men were decorated with the Virtuti Militari War Order in the years 1918-1921 (Kromp, 2012). Table 2 below shows the numbers of VLW battalions as of August 15, 1920. 
Table 2.

The number of the VLW battalions as of 15 August 1920

\begin{tabular}{|l|l|l|l|l|l|l|}
\hline \multirow{2}{*}{ Guard units of VLW } & \multirow{2}{*}{ Commander's surname } & \multicolumn{5}{|c|}{ Number } \\
\cline { 3 - 7 } VLW Lviv & $\begin{array}{l}\text { Sub-lieutenant } \\
\text { Maria Szymańska }\end{array}$ & 3 & 6 & 42 & 332 & $\mathbf{3 8 0}$ \\
\hline VLW Warsaw & $\begin{array}{l}\text { Lieutenant } \\
\text { Ludwika Rudawska }\end{array}$ & 2 & 2 & 9 & 252 & $\mathbf{2 6 3}$ \\
\hline VLW Kraków & $\begin{array}{l}\text { Sub-lieutenant } \\
\text { Józefa Pawłowska }\end{array}$ & 1 & - & 6 & 218 & $\mathbf{2 2 4}$ \\
\hline WVL Poznań & $\begin{array}{l}\text { Sub-lieutenant } \\
\text { Kamila Janota }\end{array}$ & 1 & - & 6 & 197 & $\mathbf{2 0 3}$ \\
\hline WVL Grudziądz & $\begin{array}{l}\text { Sub-lieutenant } \\
\text { Janina Kowalska }\end{array}$ & 1 & - & - & 210 & $\mathbf{2 1 1}$ \\
\hline WVL Przemyśl & $\begin{array}{l}\text { Sergeant } \\
\text { Paulina Walmoden }\end{array}$ & - & - & 4 & 250 & $\mathbf{2 5 4}$ \\
\hline $\begin{array}{l}\text { Auxiliary Company } \\
\text { Warsaw }\end{array}$ & $\begin{array}{l}\text { Sub-lieutenant } \\
\text { Zofia Kremerówna }\end{array}$ & 4 & 1 & 32 & 563 & $\mathbf{5 9 6}$ \\
\hline
\end{tabular}

Source: „Rola kobiet w walkach o kresy południowo-wschodnie Polski” by T. Grzegorczyk. Zeszyt Naukowy Muzeum Wojska Polskiego w Białymstoku no. 21/2008.

As a result of the end of the war in 1921, Poland began the process of demobilisation. The high costs of maintaining the army in peacetime caused the Ministry of Military Affairs to declare the functioning of the legions groundless. Women's service had both its supporters and opponents in society. Deserters and men who evaded the draft for obvious reasons spoke negatively about the operation of the Women's Civic Militia, but during times of greatest danger, women's service resulted in a greater belief in victory in society. Supporters argued that the service enabled men to be relieved of courier and sentry duties, and if necessary, combat operations.

Piłsudski himself, in his 1921 speech in Vilnius, expressed his clear support for women's military service, saying: I will tell you what I am thinking about now. I think that women should be drafted for military service. It is not democratic for only men to serve in the army and women not. I have already done it in the General Staff and in the Ministry of Military Affairs, which resisted, and I hope to do it in the Sejm as well (Złote myśli, 1926, p. 19).

However, the dissolution of the WVL was not the end of women's activities since in October 1922 the Social Committee of Women's Training National Defence was established, which provided for the training of women and young women for auxiliary educational, clerical, economic, communication and rescue services. However, an undeniable factor that contributed to the liquidation of the WVL was the public aversion that initially caused mistrust and even some disrespect (Odziemkowski, 1996).

As a result of the Act on General Obligation to Serve in the Military Service passed by the Polish Sejm in 1924, paragraph 62, initially included within the project and referring to women's auxiliary service, was not published. It says the following about universal military service (The Act of 23 May 1924, 1924): (...) essentially the same for all, is the personal duty of every male citizen of the Republic, and that: (...) in time of war, in addition to the obligation of universal military service, there shall be an obligation of auxiliary service. This obligation 
shall apply to all male citizens of the Republic of Poland, between the ages of 17 and 55, who are not performing military service in the regular army, in the reserves or in the army of the mass mobilisation.

The May Coup of 1926 caused Józef Piłsudski to recommend the creation of the Women's Physical Education and Military Training Department (WPEMTD), of which M. Wittek became the head (Wojskowa służba kobiet a restrukturyzacja, 2002). The above-mentioned Social Committee was authorised by the Minister of Military Affairs to conduct the preparation of personal reserves in case of war (Laszczak, 2000). As a result of this recommendation, in 1928 the Women's Organisation for the Training of Women for National Defence (WOTWND) (Pindel, 1995), which was subordinate to the Department, was set up. Eligible members were to pass on knowledge of passive anti-aircraft defence, gas defence, and the rules of assistance in the army during wartime (Odziemkowski). Military training and education continued to be provided separately for men and women. As of September 10, 1937, the Minister of Military Affairs and the Minister of Religious Denominations and Public Enlightenment issued an order that women's military service be introduced as a compulsory subject in both women's and men's high schools (Laszczak).

On April 9, 1938, a new Act on general military duty was passed, which, unlike the 1924 act, grants women the right to perform alternative military service. It states that: Women shall be subject to general military obligation if they accept this obligation voluntarily (...) (The Act of 9 April 1938, 1938). This obligation referred to auxiliary service for women between 19 and 45 years of age, who had to appear before a medical commission consisting of women and could perform this service on an equal footing with men, in the specialties listed in the Act: anti-aircraft and anti-gas defence, guard service, communication, technical, fire-fighting, military health service, transport, office service, and others, necessary for the defence of the State The Act of 9 April 1938. By 1939, however, there was still no joint military training for men and women (Laszczak).

The period of striving for independence saw a breakthrough in the creation of the first regular uniformed formation of women in the Armed Forces - the Women's Voluntary Legion (WVL). Thanks to the achievements of the WVL, women proved their military usefulness, which helped to dispel the stereotype that they were useless. The years of the Second Republic of Poland were a period of exceptional involvement of women in defence preparations and in strengthening the defence potential of the state in paramilitary organisations. 


\section{Conclusions}

All way back, Plato in his considerations saw women in military service. Although he foresaw less burdensome functions for them. These were purely theoretical thoughts as they did not match the Athenian reality. However, women did have their share in the armed act, although not all sources have been preserved, often this may have been the result of marginalising the value of their actions. The initial actions of the Samaritan women, and their increasing participation in national liberation struggles and national uprisings, slowly made their marks on pages of history. Jadwiga is mentioned as the first to perform a commanding function, and the most famous participant of the November Uprising - Emilia Plater. Initially, their functions were limited mainly to organising field hospitals, helping the wounded and sick, securing food and other aid aspects. As the Polish national spirit striving for independence strengthened, the nation solidified in its efforts to execute its right to freedom and independence. This is very much influenced by organic work and education, which strengthens the sense of patriotism and national belonging, and above all increases social consciousness, including that of the lower social strata. Only the time immediately before World War I set the pace for the development of women's military participation, and then the outbreak of war itself.

Receiving basic military training before World War I was accomplished in the form of women's participation in shooting squads, scouting or the Union of Polish Youth. Women fulfilled their duty to their Homeland by serving in the Polish Legions, the Polish Military Organization (PMO), and the Women's Voluntary Legion (WVL) (Formalno-prawne). In total, 28 women and several thousand men were decorated with the Virtuti Militari War Order in the years 1918-1921 (Kromp).

World War I saw the use of airplanes and battle gases previously unknown in combat. The arms industry was becoming an increasingly important determinant of the final outcome. The male workforce that went to the front caused them to be replaced by women in factories and manufacturing plants. Ladies began to toil in assembly lines, participating in the production of airplanes, tanks, weapons and ammunition in the broadly-defined arms industry, and working in chemical plants. They began to be employed as streetcar drivers and conductors, and operating production machinery such as cranes, lathes, and milling machines was no longer foreign to them.

External factors led to the first step in opening the door to professional careers for women, and also contributed to the rise of feminism. Despite criticism of working women in the form of neglecting their husbands, self-focus resulting from later child births and giving birth to fewer children as a result of their employment, wearing make-up (or lack thereof), or (often imagined) lack of competence, ladies from the lower social strata were facing the fact that minds were already made about them. One salary was no longer enough to support a family, and work became a necessity. In 1921, there were 83 working women for every 100 working 
men; a decade later, the ratio was already 65:100. This was the result of demobilisation and favoured employment laws for men. However, the number of working women continued to show an upward trend despite greater difficulty in finding employment, and their wages, especially in previously male-dominated industries, were between 40 and 50 percent of those received by men (https://wielkahistoria.pl, 2021). By comparison, in 1917 in Germany the number of women employed in industry alone was $17.7 \%$ higher than the number of men (Sobczyńska, 1997), while in Britain the number of 50,000 working women had increased fivefold by the end of the war (Zgórniak, 1998).

Historians recognise the time of World War I as a time of social transformation in which women became beneficiaries of won rights. By the Decree on the electoral law for the Legislative Sejm of 28 November 1918, it granted active and passive suffrage to all its citizens, regardless of gender. Article 1 of the Decree reads: The elector for the Legislative Sejm shall be every citizen of the state, without distinction of sex, at least at the age of 21 years by the date of the announcement of the election, and article 7 of the same law guarantees that the electors for the Sejm shall be all male/female citizens of the state who have the active right to vote. The first elections were held on 26 January 1919, the turnout was about 70\%, and 8 female deputies and 432 male deputies were elected to the Sejm, which was less than $2 \%$ of the women in the general composition of the chamber (Dadej, Abryszeński).

Women have the opportunity to pursue higher education. Until now, Polish women have had to seek their chances for scientific self-fulfilment abroad, where the first opportunities to study for women were offered by the Paris Sorbonne or universities in Switzerland, Belgium and England. However, the conditions that made it difficult for women to study were mainly economic factors, the crisis of the 1930s and the domination of both male colleges and vocational schools where courses of study were "appropriate for men" (Laszczak). At that time, the stereotype that women should study the humanities began to be propagated, since technical studies were reserved for men. The effects of these actions are still being remedied today, in the form of breaking stereotypes and searching for talents in the hitherto often ignored intellectual potential of the half of society made up of women. However, despite the fact that the Second Republic offered its female citizens modern legal solutions at the constitutional level, which, when converging with the banal practice of everyday life, no longer provided a guarantee of equal opportunities in their execution.

It was only the Polish authorities in exile that allowed the status of the military service of women to be regulated. This was made possible by a Decree of the President of the Republic of Poland issued on 17 October 1943, which stated that women could perform military service as volunteers on equal terms with men.

After the end of the World War I and II, women's service regained its incidental character, a phenomenon that was common throughout the world. In 1950, the first postwar law on universal defence obligation was passed, according to which only men between the ages of 18 and 50 were subject to this obligation (The Act of 4 February 1950, 1950). There have been 
sporadic cases of women being called up to the army, but the beginning of a qualitative breakthrough in this field can be found in 1988, when the recruitment of women to the military medical corps began, and then after Poland joined the North Atlantic Alliance in 1999. These changes were caused, among others, by feminist movements, demographic and economic transformations, which could not be avoided in a developing society. Women entering the labour market filled the space of the demographic decline and also supported the growing economy in which the need for physical labour began to lose its importance.

\section{References}

1. Beauvoir, S. (2003). Druga płeć. Warsaw: Czarna Owca.

2. Cieślik, A., Klimecki, M. et al. (2012). Kobiety w wojnach o niepodległość i granice 19181921. Toruń: Fundacja Generał Elżbiety Zawackiej.

3. Dadej, I., Abryszeński, P. (2019). Drogi Polek do niepodległości. Sulejówek: Zeszyty Debat Historycznych.

4. Derra, A. (2013). Kobiety (w) nauce. Problem płci we wspótczesnej filozofii nauki $i$ w praktyce badawczej. Warsaw: SCHOLAR.

5. Dufrat, J. (2001). Kobiety w kręgu lewicy niepodległościowej. Od Ligii Kobiet Pogotowia Wojennego do Ochotniczej Legii Kobiet (1908-1918/1919). Toruń: Adam Marszałek.

6. Formalno-prawne i organizacyjne aspekty wojskowej stużby kobiet (2002). Warsaw: Departament Wychowania i Promocji Obronności MON.

7. https://wielkahistoria.pl/kobiety-na-rynku-pracy-w-przedwojennej-polsce-zarabialynawet-o-50-mniej-niz-mezczyzni-co-czwarta-byla-sluzaca/.

8. Kozłowski, E., Wrzosek, M. (1984). Historia Oręża Polskiego 1795-1939. Warszawa: Wiedza Powszechna.

9. Kromp, D. (2012). Kobiety odznaczone Orderem Wojennym Virtuti Militari za walkę niepodległościową w latach 1918-1921. In: A. Cieślik, M. Klimecki et al., Kobiety $w$ wojnach Kobiety $w$ wojnach o niepodległość i granice 1918-1921. Toruń: Fundacja Generał Elżbiety Zawackiej.

10. Laszczak, B. (2000). Razem czy osobno - koedukacja w wojsku. Vademecum dydaktyczno-wychowawcze, Vol. 4. Warsaw: MON.

11. Marcinkiewicz-Gołaś, A. (2006). Ochotnicza Legia Kobiet 1918-1922. Warsaw: PAT.

12. Mrozowska, K. (1986). Kobiety polskie w nauce i oświacie. Kobiety polskie. Warsaw.

13. Nałęcz, T. (1984). Polska Organizacja Wojskowa. Warszawa: PAN.

14. Nowakowska, A. (2009). Wanda Gertz: opowieść o kobiecie żolnierzu. Krakow: Avalon.

15. Odziemkowski, J. (1996). Armia i społeczeństwo II Rzeczypospolitej. Warszawa. 
16. Pepłoński, A. (2003). Kobiety w wywiadzie Organizacji Wojskowej na Wschodzie. In: W. Rezmer (ed.), Kobiety w wojnach o niepodległość i granice 1918-1921. Toruń: Fundacja Generał Elżbiety Zawackiej.

17. Piłsudska, A. (1955). Udział kobiet $w$ walkach o niepodległość, Vol. V. London: Niepodległość.

18. Pindel, K. (1995). Działalność społeczeństwa Drugiej Rzeczypospolitej na rzecz obronności kraju w latach 1918-1939. Warsaw: AON.

19. Skrabacz, A. (2008). Stużba kobiet w formacjach mundurowych XXI wieku. Warsaw: MON CBW.

20. Sobczyńska, D. (1997). Miejsce kobiet w naukach fizyko-chemicznych. In: E. Pakszys, D. Sobczyńska (eds.), Kobiety w poznaniu naukowym wczoraj i dziś. Poznań.

21. The Act of 23 May 1924 on general military service duty. Journal of Laws of 1928, No. 46, item 458 (1924).

22. The Act of 4 February 1950 on general military duty. Journal of Laws of 1950, No. 6, item 46 (1950).

23. The Act of 9 April 1938 on general war duty. Journal of Laws of 1939, No. 20, item 131 (1938).

24. Wojskowa stużba kobiet a restrukturyzacja Sit Zbrojnych, Rada ds. Kobiet $w$ Siłach Zbrojnych (2002). Warsaw: Agencja Wydawnicza ULMAK.

25. Złote myśli Józefa Piłsudskiego (1926). Warsaw: Drukarnia Techniczna S.A. Available online https://polona.pl/item/zlote-mysli-jozefa-pilsudskiego,MjQ2OTAwODc/5/\#info: metadata.

26. Zgórniak, M. (1998). Armia obywatelska czy naród pod bronią, Siły zbrojne RP w osiemdziesięcioleciu. In: W. Wrzesiński (ed.), Do niepodległości. Wizje - drogispetnienie. Warsaw. 